\title{
Fixed laws, fluid lives: the citizenship status of post-retirement migrants in the European Union
}

\author{
LOUISE ACKERS* and PETER DWYER $\dagger$
}

\begin{abstract}
This paper presents key findings of a recently completed socio-legal study of international retirement migration in the European Union $(\mathrm{EU}) .{ }^{1}$ It highlights the diverse nature of retirement migration and the differential citizenship status that is formally granted to various groups of retired migrants. 'Citizenship of the European Union' (Articles I7-22 of the Treaty establishing the European Community) bestows important social and political rights on nationals of EU Member States ('Community nationals'). These rights are not, however, universal or based on nationality as such. In practice, the residency and social rights that a mobile EU national can claim in another Member State depend on the type of social contribution they have made and their personal relationships. Contributions through paid employment and/or membership of the family of a mobile EU worker gives rise to maximum social benefit. Whilst the European Union citizenship provisions extend residency rights to all EU nationals (irrespective of work status), those whose mobility is not connected to employment derive significantly inferior social entitlements when resident in a host Member State. Put simply, the rights of people (and members of their family) who move following retirement in their home country differ substantially from those who retire following a period of working in another Member State (and achieve the status of 'community migrant worker' prior to retirement). This formal 'discrimination' is further compounded by the diversity of the social welfare systems of the member states that results in distinct social, economic and spatial inequalities across the EU. To that extent, the 'choice' of retirement location significantly impacts on citizenship status. However, retired migrants are not merely passive spectators of formal rights and policies. Many show considerable skill in actively managing their rights (at both national and EU levels) and other resources to optimise personal benefit. This ability to maximise wellbeing is unevenly distributed.
\end{abstract}

KEY WORDS - European Union, retirement, migration, citizenship, welfare rights.

* Centre for Study of Law and Policy in Europe, University of Leeds, UK.

$\dagger$ Department of Sociology and Social Policy, University of Leeds, UK. 


\section{The development of citizenship of the European Union}

The establishment of the European Union (then the 'Economic Community') by the Treaty of Rome in I958 opened up opportunities for Community nationals to move between and reside in other Member States. Indeed, the 'Free Movement of Persons Provisions' (Articles I7-22 of the Treaty) created an embryonic citizenship which has since developed more fully and was formally constituted by the Treaty on European Union of 1993. The desire to facilitate the mobility of 'community workers' ${ }^{2}$ in a single European labour market was the key driver of this process, and encouraged the development of broader forms of social entitlement, not only for the workers themselves but also for members of their families. Those Community workers who move between Member States can now claim important forms of social entitlement in the receiving country on the basis of their status as European Citizens.

Although the European Union (EU) is not itself a welfare state, European Citizenship thus engages with national welfare systems and requires the Member States to deliver social rights to qualifying EU nationals who migrate. It does this on the basis of the non-discrimination principle (Article I2 of the Treaty). In practice this means that the receiving Member State is obliged to treat qualifying EU nationals in the same way as its own nationals. This does not imply, of course, the harmonisation of social welfare across the Member States, which continue to differ significantly in the level and nature of social welfare provision. ${ }^{3}$ Social entitlement, under EU law, derives not from citizenship status per se, but rather from the quality and location of social contribution. So, although all EU nationals have a right to move and reside in another Member State, their entitlement in that state varies considerably. The most privileged forms of benefit hinge on economic contributions in the form of paid employment. Retirement migrants (and members of their families) who have qualified as 'workers' in the host state before retirement thus derive maximum legal rights (including a right to remain), whilst those who move following retirement (and have never worked outside their 'home' country) derive little in terms of formal legal rights.

This paper presents key findings from a recently completed comparative, socio-legal, study of international retirement migration in the European Union (Ackers and Dwyer 2002). It first outlines the study's sample and method of enquiry, and then describes the development of social rights under the free movement provisions and their impact on retirement migrants. Two bases of status differentiation are examined, the concept of 'work' and 'worker' (including its implications for unpaid 
carers), and secondly, the concept of 'family' in EU law. An understanding of the concepts of family and care in Community law is important because they determine which members of worker's families gain derived rights in the host state. The discussion will be illustrated with four case histories of respondents whose moves were motivated by the need to provide care.

Community law presumes a model of familial and dependency relationships based upon a traditional 'male breadwinner' household with the (male) worker at its core and 'dependant' family members at the periphery. European Union law draws some clear if arbitrary lines between these different forms of activity, with serious implications for social status. It also presumes that these relationships are fixed in time and space. It is important to challenge these increasingly archaic assumptions of fixed categories and dependency relationships. Our empirical evidence suggests that family relationships are often characterised by fluid reciprocity and inter-dependency, and that the balance between 'dependant' and 'provider' typically shifts over the lifecourse. In practice, retirement migrants often move between legal categories repeatedly, not least as marital relationships break down and in some cases are re-constituted, or when caring relationships change direction. The differentiated and fixed nature of legal rights gives rise to potentially inefficient and inequitable consequences.

The spatial manifestation of these changes in relationships is also highly significant. To achieve optimum social protection and citizenship status, a person has to have been not only a 'worker' but more specifically engaged in the paid labour market of the host Member State. It is not enough simply to have worked all your life in your home country, for to access full rights in the host country an individual must have previously achieved the status of Community migrant worker in that country. There is thus a clear spatial dimension to the evaluation of a person's economic contribution. Arguably, there is some logic to this in actuarial terms (income tax contributions establish claims in that national system), but what if a retired person has to move to provide care for a relative who lives in another Member State? Do these forms of care not constitute economic activity and should they not therefore be rights-enhancing? Retirement migrants also contribute to local economies through consumption and indirect taxes (such as sales, value-added and property taxes). These levies constitute an increasing proportion of government income and finance a significant amount of regional and local welfare provision.

Finally, in the light of the evidence, the paper examines the relationship between legal rights and citizenship experience. Whilst we believe it is important to describe the bases and processes of status differentiation and 
to recognise that some retirement pensioners have considerably stronger formal rights than others, we would not wish to over-emphasise the determinative consequences of this situation. Retired people are not simply the passive beneficiaries or victims of legal systems. Formal legal rights constitute only one component of social status (a point often over-looked by legal analysts). The impact of legal rights on citizenship experience thus varies significantly depending upon access to other forms of resources in the mixed economy of welfare. EU-level rights interact inter alia with personal or private resources (including skills, knowledge and wealth), with national social entitlements, and with occupationally-derived benefits. Our research indicates both the importance of these other sources of benefit and the differential ability of retirement migrants to draw upon them. For some individuals, strong legal rights were not in practice exercisable, and the result was deprivation. On the other hand, some postretirement migrants with relatively weak formal rights showed great skill and creativity in managing their national and European rights and creating the best package of benefits for themselves and their families (see also Dwyer 2000, 200I).

\section{Outline of the research}

Recent studies of international retirement migration have focused on the relocation of northern European expatriates to southern Europe and particularly to Spanish coastal resorts (Rodríguez, Fernandez-Mayoralas and Rojo I998; Betty and Cahill ı999; King, Warnes and Williams 2000; O'Reilly 2000; Gustafson 200I). As the previous section has highlighted, the objectives of our study were to explore the issue of status differentiation within the diverse population of retirement migrants and specifically in the context of the elaboration of European Union law. This required a broader approach that encompassed post-migration flows in other directions (as from the UK to Ireland) and, importantly, other forms of retirement migration including specifically 'returns'. The latter comprise both the sub-set of post-retirement migrants who subsequently return home, and second, intra-EU or 'Community (labour or working age) migrants' who return to their countries of orgin when they cease work, retire or reach old age.

During the post-war period, many workers from poorer southern European countries moved in search of generally unskilled industrial employment in western Europe. ${ }^{4}$ Many of these 'Community workers' subsequently return home (some to locations favoured by retirement 
migrants). Other retired Community workers have had families, have integrated firmly with their adopted communities, retire in situ, and exercise their legal rights to remain in the host country on retirement (see Bolzman et al. 2004, in this issue). The extension of family rights under the citizenship provisions has already been mentioned. These include the right to be accompanied by a spouse, dependent children and, importantly, 'ascendant relatives', who are dependent upon the mobile Community national (in other words, any dependent parents, parents-in-law or grandparents). This identifies another group of retirement migrants, less significant numerically, who move to join their children or carers. The research therefore considers the citizenship status and experiences of five broad categories of retirement migrants:

I. Retired migrant community workers: persons who move to another Member State for work and then exercise their right to remain.

2. Returning community workers: those who move to another Member State for work and then return home on retirement.

3. Post-retirement migrants: persons who retire in the home state and then move to another EU Member State.

4. Joiners: a sub-group of the previous category who move in order to accompany or join their Community migrant children claiming rights as ascendant relatives.

5. Returning post-retirement migrants: a sub-group of category 3 (above) who subsequently return home.

The highly stratified nature of European Citizenship that derives from its foundation in an exclusive ideal of the citizen as paid worker has attracted considerable debate (Pollard and Ross 1994; Ackers 1998; Weiler 1998; Warnes 1999, 2002; Dwyer 200I; Ackers and Dwyer 2002; Kleinman 2002). Our research has brought together information about diverse retirement migrants and provided the opportunity to explore the implications of this highly differentiated status. As to methodology, the study deployed a comparative, socio-legal approach and combined legal and policy analysis with semi-structured qualitative interviews to capture the experiences of these groups (Ackers 1998). A purposive, non-random, sampling technique was adopted and interviews were carried out during I998-9. A total of 2 I0 semi-structured qualitative interviews were held; IOO with post-retirement migrants living in host EU countries, and IIO with returnees who were resident in their country of origin (for details see Ackers and Dwyer 2002: 207-II). Retirement migration is typically highly focused in terms of destinations. Return moves, particularly of category 5 above, are however more dispersed and difficult to locate. The selection 
of research areas (and partnerships) included key sending and receiving regions:

- Greece: mainly Athens and the island of Corfu with a few subjects from Macedonia in northern Greece.

- Italy: Trieste and the surrounding rural area, also around Lake Garda.

- Portugal: Lisbon and the municipalities of Sintra and Cascais.

- Sweden: the whole country.

- England and Wales.

- Ireland: Dublin and County Roscommon.

\section{'Citizenship of the Union' and the free movement rights of retired migrants}

Article I7 of the Treaty that established the European Community set out the basis of European Citizenship:

I. Citizenship of the Union is hereby established. Every person holding the nationality of a member state shall be a Citizen of the Union.

2. Citizens of the Union enjoy the rights conferred by this treaty and shall be subject to the duties imposed thereby.

The content and extent of these citizenship rights is laid out in Articles I8-2I of the Treaty. They can be summarised as: the right to move and reside freely in the $\mathrm{EU}$; the right to vote and to be a candidate in both municipal and European level elections; the right to claim diplomatic protection under the authority of another member state, and the right to petition the European Parliament. The close link between European Citizenship and the free movement of persons is immediately evident, although there is little or no reference to the implications of citizenship for non-mobile nationals. Article I8 EC states that, 'every citizen of the Union shall have the right to move and reside freely within the territory of the Member States', inferring a broad universality of status amongst Community nationals. This right is, however, made subject to 'the limitations and conditions laid down in the Treaty and by the measures adopted to give it effect'. To understand the implications of these 'limitations', one has to refer to pre-existing secondary legislation (in the form of Directives and Regulations) and the case law of the European Court of Justice (ECJ), which together implement and define the parameters of Community law.

Although the Treaty on European Union I993 formally introduced the status of 'Citizenship of the Union', citizenship rights had been evolving for some time under the 'Free Movement of Persons Provisions' (Article 39 
of the Treaty). Driven by the desire to promote labour mobility and to respond to skills shortages and regional unemployment, secondary legislation developed and was interpreted constructively by the EGJ. The result was the progressive extension of social rights for Community migrant workers and their families. The goal was always to 'facilitate the mobility' of workers. Given this objective and the fundamentally economic basis of the 'European Economic Community' (now the European Union), it is not surprising that the contributory dimension of citizenship was interpreted in strictly economic terms. The citizenship rights that evolved around the free-movement-of-persons provisions thus lead incrementally to a 'tiering' or hierarchy of entitlement, with the Community worker at the apex (c.f. Ackers I998). The subjection of the I993 Citizenship provisions to 'the limitations and conditions laid down in the Treaty and by the measures adopted to give it effect' thus confirms the continued significance of status differentiation based on economic contribution. ${ }^{\mathbf{5}}$ It is for this reason that many writers have suggested that EU Citizenship amounts to little more than a cynical public relations exercise, and that even the most substantive right (to free movement and residence) is not granted according to an individual's status as a citizen 'but in their capacity as factors of production' (Weiler i998: I3).

The status of retirement migrants exemplifies the resulting status differentiation, its basis in economic determinants, and the arbitrary and inequitable impact of Community law in this area. Whilst one might assume that all retirement migrants share a broad equality of status, at least in relation to their free movement rights within the EU, closer examination indicates otherwise. Those people who have moved during their working lives accrue important rights in the host Member State which extend into retirement and are often transportable. The close relatives of this group also derive social rights from their relationship with the workercitizen (whether they accompany or subsequently join them). These rights are, however, 'parasitic' and depend on their continued relationship with the worker-citizen. ${ }^{6}$

People who choose to remain in their home country during their working lives and exercise their free movement rights in retirement are, however, in a quite different situation. Since the Treaty on European Union I993, all Community nationals have a right to enter and reside in another Member State; indeed, even before there was a 'general right of residence'. To that extent at least there is a broad equality of status. On the other hand, a migrant's social status in the host state and the welfare claims they can make there vary considerably and depend upon their present or past relationship with the paid labour market. Whilst resident abroad, Community workers and their families are able to claim a wide 
range of employment and social rights under secondary legislation, that specifically promotes the freedom of movement of workers, and that has abolished restrictions on the movement of 'workers of Member States and their families' and promoted their parity with nationals of the host state. ${ }^{7}$ The ECJ has progressively extended the entitlement of this group to include more or less all aspects of social security or welfare benefit (meanstested or otherwise). Another piece of legislation specifically extends to these workers a 'right to remain' in the territory of a Member State following retirement with continued access to social benefit. ${ }^{8}$ Whilst EU law extends the right to enter and reside in a Member State to people who move following retirement to another EU state (never having worked in the host state), the forms of derived entitlement are highly contingent. Defined as 'economically inactive persons', their right to reside is limited by two important conditions: [that they] are covered by sickness insurance ... [and] ... have sufficient resources to avoid becoming a burden on the social assistance system of the host member state during their period of residence. ${ }^{9}$

This Article contains what is known as the 'resources requirement'. Personal resources are deemed to be sufficient to permit residence if they are above the level at which the host state grants social assistance to its own nationals. In other words, the aspirant migrant effectively has to prove that they will not make any claim against the host state's welfare system. Their status is thus markedly different from that of nationals of that country and from other 'economically active' migrants. In an interesting twist, members of this group who wish to return home after some years of residence abroad may face additional difficulties in accessing welfare rights in their home country (or region), where entitlement to certain forms of benefit and care may require them to demonstrate 'habitual residence' (Dwyer 200I; Warnes 2002). This brief summary of the free movement provisions has made apparent that social entitlements do not derive directly from nationality (as citizenship might imply), but rather from specific types of social insurance and financial contributions. EU law evidently privileges paid employment over and above other socially valuable forms of activity with an economic dimension such as informal and family care.

\section{The concept of worker in EU Law and the legal (de)valuation of care}

The following section explores aspects of status differentiation through an analysis of the concepts of 'work' and 'worker' in Community law 
(for more discussion, see Ackers and Dwyer 2002; Craig and de Búrca 2003). Its purpose is to identify those dimensions which shape the social entitlement of retirement migrants. Pre-retirement employment status in the host state is clearly a key factor. Article 39 of the 1993 Treaty and a key Regulation ${ }^{7}$ refer specifically to the 'freedom of movement for workers'. The European Court of Justice has interpreted the concept of worker broadly to encompass part-time work and irregular hours. There is no earnings threshold nor a requirement to demonstrate financial autonomy. Indeed, the Court's insistence on an 'objective' definition manifested in a ruling in Levin v. Staatssecretaris van Fustitie, a case involving the claims of a woman whose wages fell below the national minimum wage. It was successfully argued that a person's status as a Community worker depended not so much on their financial self-sufficiency but on their economic contribution. Referring to the Treaty commitment to an 'improved standard of living for workers', the Court argued that parttime work was an important and effective means of achieving that objective. In this interesting judgement, the Court showed that it is prepared to take account of changing socio-economic and cultural conditions and to argue that restricting eligibility to full-time employees would jeopardise Treaty objectives by, 'excluding very large, and probably increasing numbers of persons [including] women, the elderly and disabled' (para. I7).

In another case involving a person who sought to supplement his minimal earnings from part-time work with a claim for social security in the host state (Kempf v. Staatssecretaris van Fustitie), the Court found that reliance on social assistance did not automatically undermine his status as a worker. Such forms of work deliver full European citizenship rights provided they are not 'purely marginal and ancillary', by virtue of their economic nature, even when they are to the economic detriment of the receiving state. This is an interesting judgement given the 'resources requirement' that faces post-retirement migrants, and it draws out the arbitrary nature of existing distinctions. On the one hand, a person may qualify as a Community worker before retirement even when their income from paid employment is less than the threshold of social security. On the other hand, a post-retirement migrant has to demonstrate that he or she has sufficient resources to take them above this threshold before they can claim full residency rights in the host state. Neither of these distinctions bears any relationship to the social need of the persons concerned.

Under pressure from Member States to provide more concrete guidance, the Court set out that the 'essential feature of an employment relationship' requires that 'for a certain period of time a person performs 
services for and under the direction of another person in return for which he receives remuneration' (Lawrie-Blum v. Land Baden-Württemburg). A very broad approach to the concept of remuneration (pay) was taken in a subsequent case involving a person who undertook voluntary work for a religious community in return for 'pocket money' (Steymann v. Staatssecretaris van fustitie). Although technically unremunerated, the 'work' did 'constitute economic activities, in so far as the services which the community provides to its members may be regarded as the indirect quid pro $q u o$ for genuine and effective work'. The ruling is clearly good news for those engaged in more marginal forms of 'work'. Furthermore, if the concept of remuneration can be enlarged to include pocket-money and indirect economic 'savings' as opposed to income, then undertaking even limited part-time employment in the host state may have significant impact on the formal entitlements of post-retirement migrants. ${ }^{\mathbf{1 0}}$

The Court applied a more restrictive approach, however, in a case involving a person who was undertaking therapeutic 'work' as part of a Dutch social employment scheme (aimed at re-integrating people into the workforce). This form of 'work' did not constitute genuine and effective economic activity (Bettray v. Staatssecretaris van fustitie). ${ }^{\mathbf{1 1}}$ The implication of this case is that voluntary work or indeed unpaid caring would not qualify as 'work'. In a more recent case involving the claim of an unemployed single parent for child benefit (Sala v. Freistaat Bayern), the Court 'ducked' opportunities both to address directly the issues concerning the legal valuation of care and to challenge the current distinction between paid and unpaid work. Arguing in favour of an extension of the concept of worker to include persons who perform unwaged care-work for children, the sick and older people, Szyszczak and Moebius (I998) have suggested that the current formulation, which excludes informal care from the notion of work, 'undermines women's experience of citizenship in the European Union'. The illustrative case studies presented below indicate some of the impacts of this devaluation of care-work on the lives of both male and female retirement migrants.

European citizenship, paid work and the 'concealed multiplier of occupational success'

Titmuss's (I958) insistence on the importance of considering 'occupational welfare' as a key dimension of citizenship is highly pertinent to these issues. Writing about British social policy during the I950s, Titmuss referred to the proliferating forms of occupation-based welfare, such as the 'perks' associated with secure and well-paid employment (pensions and fringe benefits such as cars, meals and private health-insurance schemes). He was concerned that occupational welfare added a new tier to the 
pool of social resources available to people who were already advantaged. Individuals in forms of employment that did not deliver such 'perks' or those not engaged in paid work would be forced, he argued, to rely upon the typically less beneficial and less transportable forms of social welfare provision. As Irwin (1999: 7II) noted, 'the social ordering of claims and obligations and the ways in which certain groups secure or maintain an advantaged position so that work-life advantage is later translated into retirement advantage' have a crucially important influence on an individual's wellbeing in retirement.

The privileging of paid work as the basis of an individual's 'social contribution' in EU law, together with the preference for occupational and insurance-based schemes in EU policy, adds a new dimension to Titmuss's consideration of the advantages of occupational welfare. ${ }^{12}$ Citizenship of the European Union extends the ability to access domestic welfare systems (Titmuss's 'social welfare' sector) only to those persons who have previously worked in the host state (i.e. the retired Community worker). In that sense, the 'modicum of social security' available can only be accessed by those who have worked in and contributed to the host state: paid work becomes the trigger to citizenship entitlements. For the EU migrant worker, occupational welfare extends well beyond personal material rights to encompass aspects of family and immigration law.

The Community migrant worker thus has the right to be accompanied by his or her family who then derive benefit by virtue of their relationship with the worker-citizen. The social entitlement of families therefore becomes an extension of occupational status. In terms of accessing (in a host country) what Titmuss referred to as 'social' welfare rights, past employment contribution in the home state cannot be transferred and those who have resided in but not undertaken paid work in the host state (e.g. housewives and carers), do not derive independent personal entitlement. Community citizenship thus operates as an extension of occupational entitlement. Not only does it provide access to a second tier of benefits, it also determines access to basic social citizenship in the host state. In that sense, the 'multiplier effect' (i.e. the advantages accrued by those in receipt of occupational welfare) referred to by Titmuss has even greater significance. To summarise, it is clear from the ECJ's interpretation of the concept of work that while even marginal forms of paid employment are enough to enable someone to qualify as a 'worker' and therefore to achieve full citizenship status, on the other hand significant engagement in unpaid voluntary or care work does not constitute a rights-enhancing form of social contribution even when it necessitates involuntary withdrawal from the paid-labour market. 


\section{Concepts of family and dependency in EU law}

Whilst unpaid carers may not gain full citizenship rights from their 'work' as carers, they may derive an indirect entitlement (which in practice gives them the same material rights as workers) on the basis of their continued relationship with the worker-citizen. To understand what this means in practice (and who qualifies), one must consider the concept of 'a family' in European Union law. It is enunciated in a key Regulation that is specifically concerned to promote the freedom of movement of workers. It states that:

The following shall, irrespective of their nationality, have the right to install themselves in another member state with the holder of the right of residence: (a) his or her spouse and their descendants who are dependants, and (b) dependent relatives in the ascendant line of the holder of the right of residence and his or her spouse. $^{13}$

There is insufficient space in this paper to discuss in detail these provisions and their interpretation by the European Court of Justice. ${ }^{14}$ For the current discussion, one should note that 'spouse' has been interpreted to include only those persons who are legally married, and thus excludes from full entitlement co-habitees, divorcees and same-sex partners (although widows and widowers of Community workers have specifically protected rights). It is important to remember that the rights of family members are derived from their relationship with the worker-citizen. As such, non-working family members are vulnerable to relationship breakdown (which would extinguish their rights) or to a unilateral decision of the working family member to leave the country: their rights are 'coterminous' with those of the worker-citizen. It is for this reason that the rights of qualifying family members have been referred to as 'parasitic' or 'adjectival' (c.f. Blake ı999: 8; Craig and de Búrca 2003: 739).

The reference to 'dependency' in the provisions constitutes the rationale for the extension of citizenship entitlement to the families of Community workers. It has been argued elsewhere that this conceptualisation both presumes and reinforces relationships of dependency within families, between working and non-working spouses, and between parents and children (Scheiwe I994; Ackers I998; Szyszczak and Moebius I998; McGlynn 2000; Ackers and Stalford 2004). The reference to dependent relatives in the ascendant line raises similar questions for retirement migrants who exercise their right to move and join a Community worker child. At present the law assumes that these retired family members will accompany their children should the latter wish or have either to return home or to move elsewhere. 


\section{Fixed laws, fluid lives}

The clear distinctions inherent in EU law between different categories of persons on the basis of migration and marital and family/dependency status presume the existence of relatively static and predictable lifecourses and relationships. In practice, retired migrants, in common with most others, are characterised by diversity and flux. Retirement migrants are not homogeneous and the flows of people who move in later life include diverse personal and economic situations. Many migration decisions evolve incrementally and unpredictably, and some produce a series of outward and return moves in response to personal or family needs. As lives unfold, retirement migrants may move from 'snowbird' tourism to permanent residency in a host state, before contemplating a phased return 'home' (King, Warnes and Williams 2000; Ackers and Dwyer 2002). The migration trajectories of many individuals involve shifts in and out of diverse forms of mobility, each of which conveys a specific legal status.

Social planning by the EU Member States generally assumes a relatively fixed population of contributors and recipients. Faist (2001 : 40) referred to citizenship as 'the institutionalisation of generalised reciprocity and diffuse solidarity of members in a community'. This notion of reciprocity, so central to the functioning of welfare systems, is however spatially delimited because fiscal practice and actuarial processes presume a more or less static and bounded populace and a 'normal' lifecourse that proceeds from a phase of contributions to a phase of claims. In a strict sense, the conditional status of post-retirement migrants could be justified because they have not made a significant contribution (in the host state) against which to base a claim. Contribution through national insurance payments and income tax is not, however, the sole means by which social citizenship is financed. Consumption and forms of consumption-related taxation (n.b. value-added tax is high in many EU member states) form an increasing component of social income. Value Added Tax payments are 'footloose' and move with the purchaser: many retired migrants and returnees make a significant financial contribution to the local economies in which they reside. ${ }^{15}$

It is interesting that this form of direct economic contribution does not 'trigger' citizenship entitlement in the same way as paid work. Indeed, the definition of work in Community law provides full access to host welfare systems to persons who, in practice, make a minimal economic contribution and whose residence is to the economic detriment of the host state. The validity and equity of this situation needs to be considered in the light of the increasing encouragement, at EU level, of mobility during people's 
working lives. In many situations the promotion of 'peripatetic careers' (c.f. Commission of the European Communities 200i) produces repeated movements among the Member States. These movements challenge profoundly the actuarial notions that underpin European citizenship. Notwithstanding its active encouragement of labour mobility, European law rests on a narrow conceptualisation of migration behaviour - of samenationality couples making one significant move and then either remaining or eventually returning.

Not only do people move to and fro across international space, their personal relationships change. As in any population, our sample included persons who had divorced, cohabited and experienced widowhood since their initial move. Again these 'events' shift the person concerned into and out of specific legal categories that shape their social status and the claims they can make in the host and home states. The hard and fast distinctions that determine personal entitlement under Community law bear little relation to the social reality of reciprocity and inter-dependency in the lives of older people. They also raise questions around legal certainty and the enforcement and exercise of legal rights.

Furthermore, the experiences of our respondents challenge the narrowly stereotypical perceptions of retirement and old age that underpin the (lack of) rights of many older migrants in Community law. Very many respondents spoke of either making moves or indeed delaying or forgoing moves in order to provide care (rather than receive it as the law predicts). When respondents spoke directly of domestic care, 'they were often referring to migratory movements which occurred in order to provide care for other members (both children and older parents) of their families' (Dwyer 2000: 364). The evidence of a fluid and responsive reciprocity of caregiving and receiving over the life-course draws attention to the active and meaningful contribution made by retired people to the citizenship status of others, both young and old. The picture of diversity, flux and transnational care chains that emerges from our research adds weight to the case for a more inclusive and flexible conceptualisation of European citizenship. The existing situation is both discriminatory, in terms of the categories themselves, and inefficient, in the light of repeated and unpredictable status shifts. The following two case studies illustrate many of these issues. ${ }^{\mathbf{1 6}}$

\section{Mark and Helen's situation}

Mark and Helen, a British couple who had retired to Spain, were one of relatively few respondent households that had taken an elderly dependant (Susan) with them to the host state so that they could both provide care 


\section{GASE I. Mark and Helen}

Mark's mother, Susan, was already 'dependent' and lived with Mark and his wife Helen in the United Kingdom prior to their move. Susan moved with them to Spain, partly to promote her health and that of her daughter-in-law (Helen was both carer and in need of care). When Helen's health seriously declined, the family returned to the UK, but Helen and David maintained the intention of moving again once the caring relationship came to an end. As Helen said, 'It really started because I had a problem with my chest, lung trouble, and the doctor said a warmer climate would help, and Mark's mother, who lived with us, had had a stroke. A warm climate would help her health also ... we didn't stop to think about it. Underneath there was a garage and it had been dug out and we thought it would make a marvellous opportunity for Mark's mother to have a selfcontained flat under there ... we'd be off tomorrow if we could, but we are stuck for the moment with Mark's mother's failing health ... really we're in abeyance. What we've done, we've bought a little caravan, which is on the side of the property, and a sort of plan is that once we are free and able to ... we'd take the caravan over to Spain and stay with friends.

and fulfil their preferences for retirement (Case I). Moving to another Member State post-retirement meant that Mark, Helen and Susan had little formal social security entitlement in Spain. This was a keen concern for Mark and Helen who, as carers, were saving the British welfare state substantial sums yet had to manage in Spain with little State (or Community) support. ${ }^{17}$ Whilst in Spain, the three contributed to the local economy through consumption and local taxation. Their decision to return and live in a caravan raises questions about the UK 'habitual residence' rules that restricted their social security entitlements. Many other respondents had strategically maintained a residence in the UK to safeguard their rights to health and social care if they returned, but not all had the resources to do so.

\section{Oliver's circumstances}

When Oliver, an English expatriate worker, retired he moved to Spain specifically to care for his mother (Case 2). As with Anna's case (see Case 3 below), Oliver's circumstances invoke inter-generational support issues 


\section{GASE 2. Oliver}

Oliver's elderly mother, Mary, had lived with him in England since the death of her husband. When Oliver's job demanded a move to Singapore, Mary moved to her brother and sister-in-law's home in Spain. There she stayed for some 20 years until she became ill. By this time, her brother had sold up and returned. Oliver then took early retirement at the age of 54 years and moved with his wife to Spain to support Mary: she refused to return to the UK. Later, they brought her back to the UK as they were no longer able to provide the level of care she needed. Oliver commented on this sequence of events that, "Mary was, by the time I retired at the age of 82 , becoming infirm, and it had been [so] for the [previous] year: it was a case of her being ill and we had to go out there, drop everything and organise ourselves. So there she was, getting infirm, and we couldn't see how we could, on retirement, keep popping over there, because it's quite an expensive business ... amongst other things, [that] decided us that we would go and spend a few years, we thought, in the first place ... we would see her out, and then we would come back. Well, she was my responsibility, there was no one else to share it, and it seemed to be a reasonable way to have a couple of years of sunshine and sangria, if you like, and at the same time attend to her needs, because it was thought then that she had only a year or two to live. It was really [a] short-term venture, a couple of years, but it didn't turn out like that because she lived until she was 89 . So that took us into our seventh year there. [When I was 89 years of age] the local doctor said that we really ought to do something about it because she's going to have to go into some sort of care and the care there was pretty Dickensian, so we made arrangements to get her into a nursing home back in England, and that's where she spent the last nine months of her life.

and show that there is little recognition in formal social security entitlement rules of the contribution of 'younger' retired persons to the care of frail elderly relatives. The two cases evince the complex relationships between mobility histories and familial care and support, and remind us that some migrations are primarily to provide care. The experiences of 'retired carers' underline the problems that arise from existing legal categories and the characterisation of retired persons as dependent and in need of 


\section{GASE 3. Anna}

Anna was raised in Belgium and married a Portuguese man before they moved to the Congo. Since I96r she has lived in Portugal, but after her husband's death she had a very meagre income (her husband left business debts), which had been supplemented by Portuguese health and social support. When widowed, she delayed a planned return to Belgium to continue caring for her disabled son. Anna was interviewed when 79 years old, and the interviewer's notes are vivid. 'Anna's house reveals that some migrants' economic difficulties have nothing in common with most other interviewees' situations. To lessen her difficulties, Anna makes beautiful tapestries, real masterpieces, which were shown off during the interview, and sells them to her friends and to order - she works 8 to io hours a day.' Besides this income, she has a Portuguese social pension (her son's disorder created the entitlement). She has no private insurance and said, 'I have been living very poorly with the money I managed to obtain from my husband's business in the Congo. In Portugal, fish is very expensive and for almost a year I was eating a tin of sardines and rice everyday.'

Anna then mentioned the difficulties she faced in caring for her son, aged 5I years, who had Down's syndrome: 'It was difficult, much too difficult to take care of him at my age by myself. I am too old to have so much responsibility with my son. He couldn't do anything alone. My son was totally dependent on me. I didn't know anything about Portugal and [this country's] social care. ... It was a very hard time.' A friend advised her to petition Queen Fabíola of Belgium, who replied and informed her that she and her son could be helped if they moved to Belgium, and that an official would be in touch. An appointment was kept at the Ritz Hotel, and the official confirmed that unless they moved to Belgium they could not receive Belgian benefits. Anna said: 'But I couldn't do that. I really couldn't because [my son] was so well integrated here. I really couldn't make that decision. [She cried a lot.] If my son stayed here alone, I would have always felt that I abandoned him.' [She cried again.]

support. Many elderly retired people move in order to support relatives and, in the process, make a significant economic contribution and reduce pressure on public welfare provision. In other cases, retirement migrants returned home in order to care for grandchildren, so that their daughters 
could continue in employment, and to provide support and care following divorce, separation or illness.

\section{The limitations of formal equality and rights}

Whilst it is important to recognise the nature of status differentiation and the fact that some retirement pensioners have considerably stronger formal rights than others, the determinative consequences of this situation should not be exaggerated. Retired people are not simply the passive beneficiaries or victims of legal systems. In some situations, carefully crafted laws deliver rights that are not in practice exercisable. The right of a dependent person to accompany the worker-citizen is a case in point. Few examples of the effective exercise of this right were encountered, but there were many instances of the difficulties of moving highly dependent and confused very old people. The limitations of the non-discrimination principle (discussed above) also generate many problems.

\section{The circumstances of Anna and her son}

The situation of Anna, a Belgian widow living in Portugal, illustrates these limitations very well. Her painful story, of a very elderly woman widowed in the adopted country, illustrates the heterogeneity of retired migrants, the unpredictability of the lifecourse, and the acute financial needs that some migrant older people have, despite comparative affluence prior to retirement and their possession of formal European and national rights (Case 3). Furthermore, Anna's circumstances show the practical difficulties of implementing a formal right to return to the country of origin and to benefit from the Belgian social care system. While it was the son's disability and his emotional needs that barred a return move, many other cases involved care for elderly dependants. The respondents cited the onset of dementia and similar degenerative conditions as barriers to the exercise of legal rights. In material terms, Anna would have been in a stronger position had she returned to Belgium. Whilst her Community law entitlement gave her access to Portuguese services, the level of provision was low. Anna's case demonstrates the limitations of the right to nondiscrimination in the face of significant diversity and inequality in provision. In the future, she may of course need care herself. If and when this situation arises, she will find herself entirely isolated from her family and the benefits of her home state's welfare system, will have limited personal resources, and will be torn between remaining in Portugal for her son's benefit and returning to Belgium for her own. Although Anna worked an 
8-Io hour day, this was undoubtedly in the 'black economy' and did not generate social entitlements in Portugal - those that she had derived from her deceased spouse. Anna's situation raises interesting issues and represents an increasingly common situation. Whilst there are legal rights within the EU to move frail and disabled relatives to join their family abroad, often they are difficult to exercise. On the other hand, many of the entitlements to support people with disabilities and their carers are not transportable from one social security administration to another. Having to move to support a dependent relative in another state is likely to face an increasing number as more retired migrants attain advanced old age: most of them have moved without social protection and with very limited social rights in the host state. They have also put their entitlements in the home country in jeopardy.

In contrast to the situation of those who either need or provide care, formal legal EC rights make little difference to the many retirement migrants who are able to insulate themselves from social risks. Indeed, many of the retired migrant respondents in our study positively chose not to take formal residence in the host state (remaining instead as tourists), to limit their financial commitments in that country, to maximise the return on their investments, and to preserve their national entitlements.

Mobility is a resource in its own right. It also constitutes a vehicle for the exercise of agency in a wider sense, and has a determinant influence on access to other forms of social resource. The ability to exercise mobility may provide access, for example, to favourable climates, lower heating or housing costs and/or more beneficial fiscal regimes. It opens up enormous opportunities to negotiate, within a wider resource framework, access to an individually-tailored citizenship package across trans-national space. Our research has evinced the ways in which some retirement migrants are able to engage with their formal rights (at national and EU level) and to maximise their command of social resources (Ackers and Dwyer 2002; Dwyer 200I). Many cases showed the importance of recognising that for many people, residential location and migration decision-making are constantly under review.

\section{Peter and Vera's circumstances}

Peter and Vera, a Swedish retired couple, had a residential strategy that promoted both their own financial advantage and the practical support they provided for their daughter (Case 4). The case makes absolutely clear that retirement migration is inadequately described as a choice between self-centred, hedonistic preferences and sustaining family ties. Peter and Vera's residential decisions express both a concern to care for their 


\section{CASE 4. Peter and Vera}

Peter and Vera left Sweden and moved to France for income tax reasons. They talked candidly about their strategy of evading Swedish taxation and later returning to claim their social support entitlements, to which they had contributed during their working lives. This case shows the ability of some retired migrants to tailor a 'citizenship package' that optimises their access to benefits in the mixed economy of welfare and across international space. Vera said, 'Swedes usually move for financial reasons. When we moved to France, you really gained a lot because of the [lower] taxes. When we decided to go abroad, we planned to stay one year ... but that year turned into two, then five, and finally i 3 years. If you've been living in Sweden for most of your life ... then you've contributed a lot of money to Swedish society, and you want to get some use of this money. If you move to another country, you have to pay a lot of your own money, but if you return to Sweden you will at least get some of that money back.'

Peter and Vera referred to the importance of care in their migration decisions, and to their role as care providers for a divorced daughter and her children (which enabled the daughter to work), and how important these roles were to their sense of purpose. They clearly felt it was important to make an active contribution to society. Vera said: 'We have four children and one reason why we moved back to Sweden, or rather why we moved back right then and to this place, [was that] one of our daughters lives just next-door ... she's divorced and has two small children. When we moved [back] to Sweden, our grandson was one-year-old and our granddaughter four-years-old. Today, we're quite busy baby-sitting. We pick them up at the day-care centre and ... it's great ... and at the same time we're helping our daughter so that she can keep her job and ... actually I felt that way during our last years in France, because I knew that she was going through a hard time, and that she needed our help. And that was one of the reasons why we decided to move back to Sweden.' Peter added: 'Yes, and I think it's important to stress that ... if you're planning to move to another country, it's important to make sure that you have something to spend your time with ... to have some kind of meaningful task, to make sure that you're actually needed'. 
daughter and grandchild and a rational economic strategy. Their case also exemplifies migration decision-making as a process that evolves over the lifecourse in response to both predictable and serendipitous events. Many retired migrants actively seek to maximise the enjoyment of their later years through relocation. Tailoring a package of financial and social resources best able to satisfy their personal requirements and needs is an important element in their migration decisions and movements. Many retirement migrants are resourceful in negotiating and re-negotiating the most advantageous welfare 'deal'. If detrimental changes to their medical or financial circumstances indicate another move, they pursue the goal single-mindedly. In the words of one Swedish returnee: 'When you move abroad, you have to be curious and daring, but when it comes to returning to your home country you have to be very calculating and well organised. It's a kind of conflict I suppose'. When considering such decision-making and actions, the distinction between 'benefit shopping' or 'welfare tourism' and 'reflexive or active citizenship' - as envisaged by Giddens (I994) - is finely drawn.

Our research suggests that migration poses increasingly serious challenges to the future of social citizenship and social institutions. At the present time, citizenship entitlements are firmly based on spatially delimited forms of economic contribution, and are incapable of responding to the increasingly fluid nature of people's lives. Whilst this significantly disadvantages some individuals, it also generates clear opportunities for 'cherry picking' and the careful manipulation of European and national systems. This is generating new forms of inequality and privilege, not least among older people. Our study suggests that the ability to engage in this form of negotiation and to manage a rights package to maximum effect is unevenly distributed and depends on the following factors:

- the differential status of citizens under EC law reflecting nationality, work status and family roles;

- the variable availability and quality of national and regional social infrastructures;

- employment histories and the relative balance of reliance upon contributory and non-contributory benefits, and their association with both the quantity and quality (transportability) of benefits;

- access to personal wealth, particularly to support second-home ownership as a basis for residency-based entitlements in two or more locations;

- knowledge of options and rights and how to exercise them;

- individual health and family status at any point in time. The unpredictability of lifecourses and the consequence of long-term chronic 
illnesses and bereavement may rapidly exhaust even considerable resources.

\section{Conclusions}

From a legal point of view, international retirement migrants should be recognised as comprising several groups with different formal statuses. The movement of retired people thus provides an interesting case of contemporary processes of status differentiation. It reveals important distinctions based on the quantity and nationality of different forms of social insurance and other financial contributions. Paying contributions in the home state during one's working life and then migrating on retirement has different implications to moving as a worker or worker's dependant and retiring in situ. Subsequent return also has legal implications. Furthermore, for those people (mainly women) who have either taken time out of the labour market to care for families, or whose labour market participation has been disrupted by a partner's employment, mobility may create a less advantageous, derived status. Accompanying partners and relatives who fall outside Community definitions of family or dependency may be further disadvantaged. The evolution of family relationships, economic roles and migration trajectories over the lifecourse thus shape the legal entitlement of retired migrants. That entitlement translates into a differential ability to 'plug' into domestic welfare systems and claim social resources. These categories bear little relation to demonstrable need but rather reflect the incremental way in which EU social citizenship rights have evolved and test the parameters of Community competence.

Our study sought to understand the relationship between formal legal rights, social policy infrastructures in the participant countries and citizenship practice. The project has elucidated many limitations of the capacity of 'Citizenship of the Union' to deliver a more egalitarian and inclusive European social space. Simultaneously, it has identified some key challenges that migration poses for social policy. Five conclusions can be drawn from the research. First, the level and nature of formal status differentiation among retired migrants significantly restricts the inclusive potential of 'Citizenship of the Union'. Second, 'Citizenship of the Union', as it stands, amplifies the advantages attached to occupational welfare and compounds the relationship between the social division of labour and wellbeing. These processes are gendered. Third, in addition to distinctions in formal rights, the citizenship status and wellbeing of migrants reflects the diversity of social policy infrastructures and welfare systems across the European Union and raises serious questions about distributive justice. Fourth, people 
are not passive spectators of formal rights and policies: legal rights, although important, do not have a determinative effect but are one dimension of people's resource framework. Both the quality and quantity of social resources are variable, and retired migrants show considerable skill in managing their individual situation. The ability to maximise wellbeing is, however, unevenly distributed. Fifth, the evidence of individual agency, that is, the willingness to negotiate contributions and rights, and to manipulate advantage across geographical and social space raises serious challenges for European and domestic welfare systems.

\section{Acknowledgements}

The authors thank The Wellcome Trust for a grant to fund the research which informs this paper (Grant 048853). Thanks also to all the partners and respondents who took part in the fieldwork and to Suzanne Hallam and the anonymous referees for comments on a previous draft.

\section{NOTES}

I Further details of this work and findings are presented in Ackers and Dwyer (2002).

2 It is important to stress that these rights do not accrue to third country nationals at the present time, even if they are legally resident in the EU, but only to those persons who hold the nationality of one of the Member States. In the article we have referred to these people as 'Community nationals' or 'Community workers'.

3 The principle of 'subsidiarity' (Article 5 of the Treaty) seriously restricts the legal competence of the European Union in the field of social policy and permits the persistence of social diversity and inequality. A 'Protocol on the application of the principles of subsidiarity and proportionality' is annexed to the Treaty.

4 This is an historically specific movement and the context has undoubtedly shifted in the last 50 years. Nevertheless, enlargement may augment these patterns of migration including post-retirement returns.

5 There is controversy over the legal effect of Article i7. For a discussion see Craig and de Burca (2003: 755-6I).

6 The negative implications, particularly for women, of attaching rights to an individual's status as a European worker rather than a citizen, have been commented on elsewhere. Levitas (1998) noted an 'endemic' preoccupation with paid work in the legal and financial framework of the EU that fails to take into account the unpaid domestic labour of many women.

7 Regulation (EEC) I6I2/68 and Council Directive 68/36o/EEG respectively.

8 Regulation (EEG) I25I/70.

9 Article I, Council Directive 9o/365.

Io Indeed, many retirement migrants do re-commence forms of paid work in the host state probably unaware of the significance of this in terms of their legal rights!

II In a recent ruling, the Court has confined Bettray to its specific facts and ruled that a post organised and funded by public authorities may nevertheless constitute legal 
employment. See Case C-I/97 Mehment Birden v. Stadgemeinde Bremen, judgement of 26 November 1998.

I2 Titmuss's reference to 'fiscal welfare' is also relevant in the context of retirement migration as we shall see later.

I3 Regulation (EEC) I612/68.

I4 Please refer to Ackers and Dwyer (2002: 35-62), Chapter 3, 'Shades of citizenship: the legal status of retirement migrants', for further discussion.

I5 Just as remittances have been shown to contribute significantly to local economies (see King 1986).

I6 The book based on the research contains many more qualitative findings.

I7 Although the health care system in Spain is now reported as being very good, many respondents remarked on the lack of a community-care 'culture' and the associated support services.

\section{References}

Ackers, H. L. 1998. Shifting Spaces: Women, Citizenship and Migration within the EU. Policy, Bristol.

Ackers, H. L. and Dwyer, P. 2002. Senior Citizenship? Retirement Migration and Welfare in the European Union. Policy, Bristol.

Ackers, H. L. and Stalford, H. 2004. A Community for Children? Children, Citizenship and Internal Migration in the EU. Ashgate, Aldershot, Hampshire.

Betty, C. and Cahill, M. I999. British expatriates' experience of health and social services on the Costa del Sol. In Anthias, F. and Lazaridis, G. (eds), Into the Margins: Migration and Social Exclusion in Southern Europe. Avebury, Aldershot, Hampshire, 83-I13.

Blake, N. I999. Family life in community law: the limits of freedom and dignity. In Guild, E. (ed.), The Legal Framework and Social Consequences of Free Movement of Persons in the European Union. Kluwer Law, London, 7-I9.

Bolzman, C., Poncioni-Derigo, R., Vial, M. and Fibbi, R. 2004. Older labour migrants' well-being in Europe: the case of Switzerland. Ageing \& Society, 24, 3, 4I I-30.

Commission of the European Communities (CEC) 200I. New Labour Markets, Open to All with Access for All. COM 200I, CEC, Brussels.

Craig, P. and de Búrca, G. 2003. Cases and Materials, 3rd edition. Oxford University Press, Oxford.

Dwyer, P. 200o. Movements to some purpose? An exploration of international retirement migration in the European Union. Education and Ageing, I5, 3, 352-77.

Dwyer, P. 200I. Retired EU migrants, healthcare rights and European social citizenship. fournal of Social Welfare and Family Law, 23, 3, 31 I-27.

Faist, T. 200I. Social citizenship in the European Union: nested membership. Fournal of Common Market Studies, 39, I, 37-58.

Giddens, A. 1994. Beyond Left and Right: The Future of Radical Politics. Polity, Cambridge.

Gustafson, P. 200I. Retirement migration and transnational lifestyles. Ageing E Society, 2 I, $37 \mathrm{I}-94$.

Irwin, S. I999. Later life, inequality and social theory. Ageing $\mathcal{E}$ Society, r 9, 6, 69I-7I5.

King, R. (ed.) 1986. Return Migration and Regional Economic Problems. Croom Helm, London.

King, R., Warnes, A. M. and Williams, A. M. 2000. Sunset Lives: British Retirement Migration to the Mediterranean. Berg, Oxford.

Kleinman, M. 2002. A European Welfare State? European Union Social Policy in Context. Palgrave, Basingstoke, Hampshire.

Levitas, R, 1998. The Inclusive Society? Social Exclusion and New Labour. Macmillan, Basingstoke, Hampshire. 
McGlynn, C. 2000. A family law for the European Union? In Shaw, J. (ed.), Social Law and Policy in an Evolving European Union. Hart, Oxford, 223-43.

O'Reilly, K. 2000. The British on the Costa del Sol: Transnational Identities and Local Communities. Routledge, London.

Pollard, D and Ross, M. 1994. European Community Law: Texts and Materials. Butterworth, London.

Rodríguez, V., Fernández-Mayoralas, G. and Rojo, F. I998. European retirees on the Costa del Sol: a cross-European comparison. International fournal of Population Geography, $\mathbf{4}$, I83-200.

Scheiwe, K. I994. EC law's unequal treatment of the family: the case law of the European Court of Justice on rules prohibiting discrimination on grounds of sex and nationality. Social and Legal Studies, 3, 243-65.

Szyszczak, E. and Moebius, I. I998. Yearbook of European Law, 18, 125-56.

Titmuss, R. M. 1958. The social division of welfare. In Titmuss, R. M. (ed.), Essays on the Welfare State. Allen and Unwin, London, 34-55.

Warnes, A. M. I999. Divided responses to an ageing population: apocalyptic demography, ideology and rational social administration. In Hudson, R. and Williams, A. (eds), Divided Europe. Sage, London, 23 ${ }^{-}-54$.

Warnes, A. M. 2002. The challenge of intra-Union migration to social Europe. Fournal of Ethnic and Migration Studies, 28, I, I35-52.

Weiler, J. 1998. Introduction: European citizenship, identity and differentity. In La Torre, M. (ed.), European Citizenship: An Institutional Challenge. Kluwer Law International, The Hague, IO-2I.

Address for correspondence:

Accepted I4 October 2003

Louise Ackers, Gentre for Study of Law and Policy in Europe, University of Leeds, Leeds $\mathrm{LS}_{2}$ 9JT, UK.

e-mail: H.L.Ackers@leeds.ac.uk 